
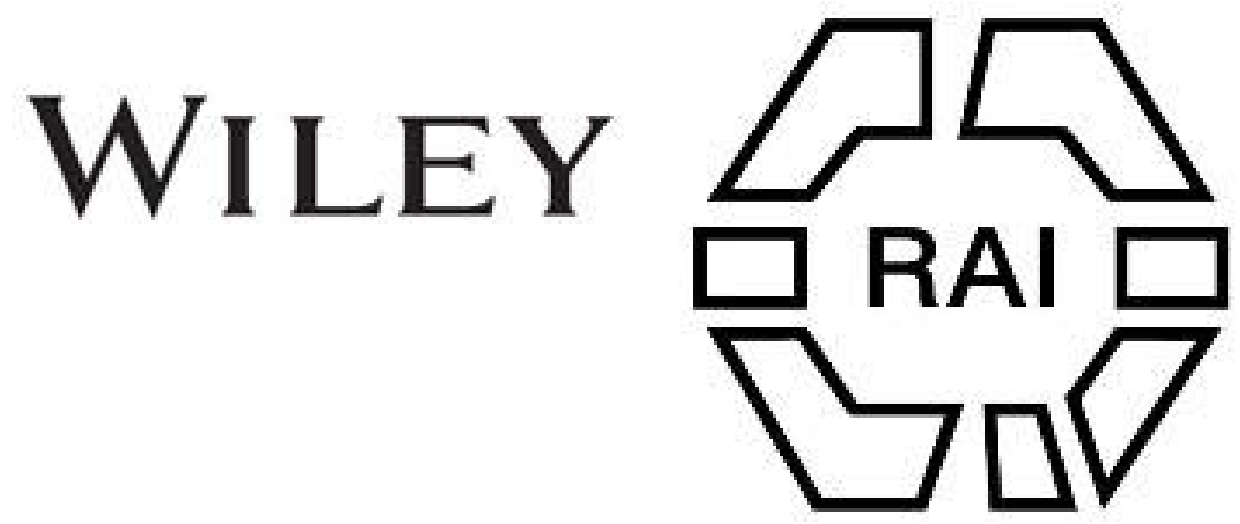

\title{
104. Secret Bargaining
}

Author(s): T. C. Hodson

Source: Man, Vol. 13 (1913), p. 193

Published by: Royal Anthropological Institute of Great Britain and Ireland

Stable URL: http://www.jstor.org/stable/2787592

Accessed: 27-06-2016 02:26 UTC

Your use of the JSTOR archive indicates your acceptance of the Terms \& Conditions of Use, available at

http://about.jstor.org/terms

JSTOR is a not-for-profit service that helps scholars, researchers, and students discover, use, and build upon a wide range of content in a trusted digital archive. We use information technology and tools to increase productivity and facilitate new forms of scholarship. For more information about JSTOR, please contact support@jstor.org.

Wiley, Royal Anthropological Institute of Great Britain and Ireland are collaborating with JSTOR to digitize, preserve and extend access to Man 


\section{ORIGINAL ARTICLES.}

\section{$\begin{array}{lrl}\text { Egypt : Sudan. With Plate M. } & \text { Seton-Karr } \\ \text { Ancient Mealing Holes at Jebelain, Sudan. } & \text { By H. W. Seton-Karr. }\end{array}$ \\ $\begin{array}{ll}\text { Egypt : Sudan. With Plate M. } & \text { Seton-Karr. }\end{array}$ \\ I have returned from a trip up the White Nile, and the photographs of 10} some examples of hollows for mealing grain were taken by me in January 1913. These are found in numerous spots round the bases of the isolated granite peaks of Jebelain, about 60 miles south of Kosti or Goz-abu-Guma, where the Sudan Railway to El Obeid, in Kordofan, crosses the river. In the vicinity of these mealing holes broken grinding-stones can be picked up. The holes or hollows are more numerous near the river than on the more distant peaks.

There would seem to have been a numerous population at one time.

A great period of time may have elapsed since they were last in use. There are no other ancient remains visible and no ruins are seen at Jebelain. The word means two peaks, but there are in reality three, and numerous smaller ones.

The surrounding country is perfectly flat and covered with thorn trees. The rocks at the base are the resort of wild animals, and I killed a panther, two hyenas, and four lions in the neighbourhood this year.

H. W. SETON-KARR.

India.

Hodson.

Secret Bargaining. By $T$. C. Hodson.

When the person wishing to buy denotes a hundred, he takes one finger of 104 the person to whom he makes the offer, in his hand, grasps it firmly, and mentions in a whisper the word, Pakka, and for every additional hundred he takes a finger. When 5 rupees are mentioned, then the word Dana is whispered, and one finger is grasped for every 5 rupees mentioned, e.g., 25 rupees for five fingers. When a single rupee is offered one finger is grasped and the word Sute is whispered. A bargain made by the above means is to be kept secret during the mela or till the buyer leaves the place of purchase, and this is very strictly adbered to. An offer made by this means is not disclosed by either party, and it would be a great breach of etiquette to do so. Offers made and accepted by this scheme are regarded as final and binding.

(From a private letter.)

T. C. HODSON.

\section{Archæology.}

Elliot Smith.

The Origin of the Dolmen. By G. Elliot Smith, F.R.S.

Since Reisner explained (1908) the mode of evolution of the mastaba type

of superstructure, which in its fully-developed form as a stone construction is so characteristic a feature of the Egyptian tomb of the Pyramid Age, Mace (1909),* Quibell (1912), $†$ Junker (1912), $\ddagger$ and Flinders Petrie (1913), § have supplied the data 'which complete and corroborate the story. In the light of this recently-acquired knowledge of the gradual transformation of the Egyptian grave (a process that occupied the five or six centuries from 3400 B.C. onward) to meet conditions peculiar to Egypt, and to overcome difficulties incidental to the practice of Egyptian beliefs, it is altogether inconceivable that the more or less crude, though noue the less obvious imitations of the essential parts of the fully-developed mastaba, which are seen in the Sardinian "Giants' Tombs," the allées couvertes of France and elsewhere, the widespread "holed dolmens," and all the multitude of "vestigial structures," to use a biological analogy, represented in the protean forms of the Algerian and Tunisian dolmens, could have been invented independently of the Egyptian constructions.

* G. A. Reisner and A. C. Mace, "Early Dynastic Cemeteries at Naga-ed-Dêr, 1908 and 1909.

† J. E. Quibell, "Excavations at Saqqara," paper read at British Association meeting, 1912.

$\ddagger$ Hermann Junker, Denkschr. d. k. Akad. d. Wissensch. in Wien, Bd. LVI, 1912.

$\$$ W. M. Flinders Petrie, "Excavations at Tarkhan," paper read at British Association meeting 1913. See also MAN, 1913, No. 85.

$$
\text { [ } 193]
$$

